\title{
Financiële topmanagers over hun
}

\section{vermogensstructuur}

\section{Drs. Kees Cools}

'Much of what is relevant to corporate financial decisions is not capital market-revealed; it is hidden from external view. It simply is easier to concentrate on the external dimension of finance - stock market prices and interest rates.'

W. T. Carlton (1978)

\section{Inleiding ${ }^{1}$}

Ter afsluiting van het drieluik over de vermogensstructuur van ondernemingen wordt in dit artikel de praktijk aan het woord gelaten ter beantwoording van de vraag 'Hoe bepalen ondernemingen hun financiële structuur?' In het eerste artikel (Cools, 1990) werd een beknopt overzicht gegeven van de neo-klassieke financieringstheorie van de vermogensstructuur sinds Modigliani en Miller (1958). Daarna werd in Cools en Spee (1990) een empirische analyse uitgevoerd van de vermogensstructuur van Nederlandse beursondernemingen voor de periodes $1977-78$ en 198687. Daaruit bleek dat het bedrijfsrisico, de omvang van de onderneming en de winstgevendheid de belangrijkste bepalende factoren zijn van de financiële structuur. Ter completering van het beeld worden in dit artikel enkele resultaten besproken van vraaggesprekken met bestuurders die verantwoordelijk zijn voor de financieringsbeslissingen van vijftig Nederlandse beursondernemingen, waaronder de dertig grootste. $^{2}$ Uit de vraaggesprekken blijkt dat het weerstandsvermogen het belangrijkste aspect van de vermogensstructuur is. Voorts komt scherp naar voren dat het bedrijfsrisico de pri- mordiale determinant is van de gewenste vermogensstructuur; naarmate het bedrijfsrisico groter is streeft men naar een lager financieel risico, derhalve een hogere solvabiliteit. Het bedrijfsrisico wordt daarbij met name bepaald door de activasamenstelling van de onderneming.

\section{Waarom vraaggesprekken?}

Elke onderneming is tot op zekere hoogte uniek. Daarom mag men ook niet verwachten gemakkelijk universele wetmatigheden ter verklaring van de (optimale) vermogensstructuur te kunnen vinden. In Cools (1990) werd toegelicht dat de financieringstheorie niettemin in staat is gebleken een aantal factoren aan te geven die mede bepalend zijn voor de financiële structuur van een onderneming. De verklaringskracht van enkele modellen uit het empirisch onderzoek van Cools en Spee (1990) was weliswaar hoog, maar statistische analyse van historisch cijfermateriaal kent als methodiek haar beperkingen. Belangrijke determinanten van de vermogensstructuur laten zich nu eenmaal niet zonder meer vertalen in jaarrekening-cijfers of aandelenkoersen, aanvullende informatie is daarvoor nodig. Daarnaast moeten we minimaal enig inzicht hebben in de doelstellingen en motieven van een onderneming voordat we zinvol iets kunnen zeggen over de optimale vermogensstructuur. Ook gegevens over ondernemingsdoelstellingen en motieven van het management vinden we niet rechtstreeks terug in het jaarverslag. Bovendien krijgt men soms de

Drs. C. Cools, registeraccountant, studeerde economie en filosofie en is verbonden aan de vakgroep

Bedrijfseconomie, sectie Financiering, van de Katholieke Universiteit Brabant. 


\section{MAB}

indruk dat, drie decennia na Modigliani en Miller, het onderzoek naar de vermogensstructuur enige tekenen van inertie vertoont; het is een belangrijk en interessant probleem maar grote stappen voorwaarts worden niet meer dagelijks gezet.

Het ligt daarom voor de hand om door middel van vraaggesprekken met financiële topmanagers te komen tot een diepergaande analyse en zo mogelijk meer realistische verklaring van het financieringsgedrag van ondernemingen. Tevens zou met deze informatie uit de praktijk een positieve impuls kunnen worden gegeven aan het huidige theoretisch onderzoek. Tegelijkertijd zou dit de discussie tussen de financiële ondernemingspraktijk en de financieringstheorie kunnen bevorderen.

Bij economisch onderzoek in het algemeen, en binnen de financiële economie in het bijzonder, is het geen alledaagse praktijk om enquêtes of vraaggesprekken als onderzoekstechniek te hanteren. ${ }^{3}$ Voor andere menswetenschappen daarentegen, zoals sociologie en psychologie, is het minder buitensporig om ter verklaring van menselijk gedrag de meest voor de hand liggende weg te bewandelen en het onderzoekssubject direct te vragen naar zijn drijfveren en motieven. Een reden voor dit verschil in onderzoekscultuur kan te maken hebben met het feit dat in de economie de prijsvorming en allocatie van schaarse goederen centraal staan, welke beide waarneembaar zijn en het gedrag weerspiegelen van velen. Het heeft daarom sterk de voorkeur prijsontwikkelingen te analyseren in plaats van honderden consumenten of beleggers te interviewen over de motieven van hun koop- en verkoopgedrag.

Voor beleggingsleer (investments) is de verklaring van aandelenkoersen doel van het onderzoek, terwijl koersen bij ondernemingsfinanciering (corporate finance) slechts een middel zijn voor de bestudering van het gedrag van ondernemingen. Een cruciale voorwaarde voor een zinvolle bestudering van aandelenkoersen ter verklaring van het financieringsgedrag van ondernemingen is de maximalisatie van de marktwaarde van het eigen vermogen als gepostuleerd ondernemingsdoel. Indien echter zou blijken dat het bestaan van deze navelstreng tussen de onderneming en de kapitaalmarkt twijfelachtig is, dan kunnen we niet langer beschikken over een grootheid (koersen) waarin zich de motieven van een onderneming weerspiegelen. Dit zou het geval zijn wanneer de onderneming een ander doel nastreeft, of wanneer 'de onderneming' als zodanig niet bestaat, maar we beter zouden kunnen spreken van een 'nexus of contracts' zoals gesuggereerd door Jensen en Meckling (1976). In beide gevallen zouden we, naast aandelenkoersen en jaarrekeningen, zijn aangewezen op aanvullend empirisch materiaal.

Informatie over het doel van een onderneming kan worden verkregen door dit te vragen aan het topmanagement. Een belangrijker argument echter voor het houden van vraaggesprekken is de constatering dat de theorie tot op heden niet in staat is gebleken alle relevante determinanten van de vermogensstructuur te achterhalen. Bovendien moeten we nog altijd rekening houden met de mogelijkheid dat met een 'optimale' financieringsbeslissing weinig of geen waarde aan de onderneming kan worden toegevoegd, waarmee de keuze van de vermogensstructuur relatief onbelangrijk wordt. De vermogensstructuur komt dan op toevallige wijze tot stand en zou dus even goed kunnen worden 'verklaard' als de uitkomst van een roulettespel. Daarmee hangt samen de mogelijkheid dat niet zozeer de verhouding eigen/ vreemd vermogen van belang is maar veeleer andere facetten van de financiële structuur zoals garantievermogen, looptijd, rentedekking, enzovoort.

Tenslotte, een bezwaar van vraaggesprekken als onderzoekstechniek kan zijn dat de geïnterviewde redenen heeft om weliswaar de waarheid te spreken maar niet de hele waarheid. Het ligt voor de hand dit te verwachten bij vragen over belastingontduiking, insider trading, maatschappelijk ongewenst gedrag of koersgevoelige onderwerpen. Voor de onderwerpen die in deze vraaggesprekken aan de orde zijn gesteld is het gevaar voor vertekeningen in de antwoorden minder waarschijnlijk. Bovendien wordt de kans op vertekening verkleind doordat de gesprekken 


\section{MAB}

vertrouwelijk zijn en over individuele antwoorden geen mededeling wordt gedaan.

\section{De vraaggesprekken}

De vraaggesprekken zijn gehouden met leden van de raden van bestuur van vijftig Nederlandse beursondernemingen, die verantwoordelijk zijn voor het financiële beleid, in het bijzonder de financiering van de onderneming. ${ }^{4}$ In bijlage 1 treft $u$ een lijst aan met de namen van de betreffende personen en ondernemingen. De groep van vijftig ondernemingen bestaat uit de dertig grootste beursfondsen plus twintig minder grote genoteerde ondernemingen. De grootste dertig zijn opgenomen omdat daarmee het financiële gedrag van maar liefst $75 \%$ van de totale marktwaarde van niet-financiële ondernemingen in kaart wordt gebracht. Bij de selectie van de overige twintig is gestreefd naar een zekere spreiding over branches en in het bijzonder naar 'aantal jaren op de beurs'.

Om twee redenen was het van belang om de vragen voor te leggen aan de financiële eindverantwoordelijke binnen elke onderneming. Op de eerste plaats hebben de vragen betrekking op de hoofdzaken van het financiële beleid waarbij met name de achtergronden en motieven van de financieringsbeslissingen aan de orde worden gesteld. Op de tweede plaats hebben enkele vragen betrekking op ondernemingsdoel, stakeholders en de waardering van de onderneming. Het verdient de voorkeur dergelijke vragen te stellen op het hoogste niveau van de organisatie, daar waar het strategisch beleid wordt bepaald.

De gemiddelde duur van de gesprekken bedroeg twee uur en een kwartier, de gesprekken zijn op band opgenomen en uiteraard is aan ieder dezelfde lijst met vragen voorgelegd. Slechts één onderneming (Gist Brocades) heeft niet aan het onderzoek mee willen werken, waardoor de nonresponse kleiner is dan $2 \%$. De geïnterviewden hebben aan het onderzoek hun medewerking verleend onder de garantie van strikte vertrouwelijkheid. Dit betekent dat gegevens over individuele ondernemingen niet zullen worden gepubliceerd en dat niet in naam zal worden geciteerd.

\section{Ondernemingsdoel en -waarde}

Zoals aangegeven in Cools (1990) is een fundamentele aanname van de neo-klassieke theorie van de ondernemingsfinanciering (corporate finance) dat ondernemingen streven naar maximalisatie van de marktwaarde van het eigen vermogen. In de mate waarin dit doel minder op de voorgrond staat c.q. de aandeelhouder een minder belangrijke rol speelt, moet aan agency mechanismen een grotere rol worden toegekend. In het bijzonder ter verklaring van de vermogensstructuur zal dan bijzondere aandacht moeten worden geschonken aan agency mechanismen tussen aandeelhouders en management. ${ }^{5}$

Mede in relatie tot het ondernemingsdoel maakt Moerland (1989) een onderscheid tussen enerzijds de meer institutionele opvatting van ondernemingen in continentaal Europa waarbij niet uitsluitend gehandeld wordt in het belang van de (eigen) vermogensverschaffer maar diverse deelbelangen zijn geïntegreerd. Anderzijds de Angelsaksische landen waar de 'corporate enterprise' strikt genomen wordt opgevat als een verlengstuk van de aandeelhouders. Teneinde te toetsen of Nederlandse beursondernemingen werkelijk streven naar marktwaardemaximalisatie zijn vragen gesteld over ondernemingsdoel en de rol van verschillende stakeholders. Tabel 1 geeft een inzicht in de primaire doelstellingen van de betrokken ondernemingen. Het resultaat spreekt voor zich, slechts $6 \%$ streeft naar maximalisatie van de aandeelhouderswaarde ('Wij willen op lange termijn het rendement van onze aandeelhouders maximaliseren'). Aan agencymechanismen tussen aandeelhouders en management zal derhalve een belangrijke rol moeten worden toegekend bij de verklaring van de vermogensstructuur. De $8 \%$ die uitsluitend naar continuïteit streeft betreft ondernemingen die slecht presteren en slechts aan overleven denken, een streven naar winstgevende groei is van later zorg. Het tegenovergestelde is aan de orde bij de $8 \%$ die slechts groei noemt als doelstelling. Dit zijn uitsluitend ondernemingen waarvan de rentabiliteit over de afgelopen 5 jaar buitengewoon hoog is geweest. Verschillen in ondernemingsdoelstel- 


\section{MAB}

ling blijken niet significant gerelateerd te zijn aan ondernemingsgrootte of bedrijfstak.

\section{Tabel 1: Primaire doelstelling van de onderneming}

Winstgevende groei, gericht op continuïteit

$78 \%$

Continuïteit zonder meer

Winstgroei zonder meer

Maximalisatie van de aandeelhouderswaarde

$8 \%$

$8 \%$

$6 \%$

$100 \%$

Tevens is de vraag gesteld of er een hiërarchie is aan te geven van bij de onderneming betrokken stakeholders. Dit geeft een inzicht in de rol van aandeelhouders, en vormt indirect een indicatie voor het belang van waardemaximalisatie van het eigen vermogen als ondernemingsdoelstelling. Ook hier blijkt dat de verschillen tussen ondernemingen groot kunnen zijn, variërend van 'Wij dienen het belang van onze aandeelhouder' tot 'Alleen de aandeelhouder speelt niet mee' en 'Aandeelhouders, ja, daar wordt een keer per jaar jus d'orange voor geschonken', maar het totale beeld is duidelijk. Uit tabel 2 blijkt immers dat slechts $8 \%$ de aandeelhouder op de eerste plaats zet.

In het geval van drie van deze vier ondernemingen is er echter sprake van een grootaandeelhouder die minimaal $50 \%$ van de aandelen in handen heeft. Dit ondersteunt de eerdere constatering dat Nederlandse ondernemingen niet streven naar maximalisatie van de aandeelhouderswaarde. Tegelijkertijd vormt het een treffende illustratie van het fenomeen dat agency problemen tussen aandeelhouders en management sterk afnemen in het geval van geconcentreerd aandeelhouderschap.

Tabel 2: Belangrijkste stakeholder

Geen voorkeur

Klant

Personeel

Leverancier

Aandeelhouder
$52 \%$

$22 \%$

$14 \%$

$4 \%$

$8 \%$

$100 \%$
Het relatief geringe belang dat men aan aandeelhouders toekent komt ook naar voren uit het feit dat voor $38 \%$ van de ondernemingen de aandeelhouder van geen belang is of pas op de laatste plaats komt. Het is overigens opvallend dat twee van de drie ondernemingen die maximalisatie van de aandeelhouderswaarde als ondernemingsdoel hanteren, de aandeelhouder niet als belangrijkste stakeholder noemen. Men zou kunnen zeggen dat het 'aandeelhoudersstreven' van beide ondernemingen met enige voorzichtigheid moet worden geïnterpreteerd. Er resteert dan nog slechts één onderneming die de aandeelhouders werkelijk van primordiaal belang acht, te meer daar deze geen grootaandeelhouder heeft.

Het zal niet verbazen dat voor de $4 \%$ die de leverancier als voornaamste stakeholder noemen, het inkoopresultaat de belangrijkste winstbepalende factor is. Voor de overige ondernemingen zijn de verschillen in belangrijkste stakeholder niet significant gerelateerd aan winstgevendheid, ondernemingsomvang of bedrijfstak.

Om redenen van maximale betrouwbaarheid is niet gevraagd naar de positie van een van de belangrijkste stakeholders, het management zelf. Wel is het opvallend dat $42 \%$ uit eigen beweging het management aan de lijst toevoegde en daarbij door $38 \%$ als eerste in de hiërarchie werd geplaatst ('Je denkt natuurlijk in eerste instantie als management aan jezelf'). Dit onderstreept nogmaals het belang van agency relaties.

\section{De gewenste vermogensstructuur}

Bij empirisch onderzoek naar determinanten van de vermogensstructuur doet zich een lastig probleem voor: de gewenste vermogensstructuur is namelijk niet waarneembaar. Uitsluitend de feitelijke vermogensstructuur in termen van boekwaarden kunnen we per balansdatum aflezen in de balans, waarbij we dan nog afzien van off balance sheet financiering zoals operational lease, niet geconsolideerde lease- of onroerendgoedmaatschappijen, valuta- en termijncontracten, factoring, enzovoort. ${ }^{6}$ Of, en zo ja in welke mate de feitelijke vermogensverhoudingen verschillen van de gewenste vermogensstructuur is geheel onduidelijk. De meeste theorieën geven 


\section{MAB}

echter een verklaring voor de gewenste financieringsstructuur. Voor empirische studies, inclusief Cools en Spee (1990), heeft dit tot gevolg dat men gedwongen is te veronderstellen dat de feitelijke vermogensstructuur gelijk is aan de, niet waarneembare, gewenste vermogensverhoudingen. In hoeverre tegenvallende resultaten van empirisch onderzoek te wijten zijn aan deze wellicht heroïsche veronderstelling stond tot nu toe in de sterren geschreven. De oplossing voor dit probleem ligt echter voor de hand, vraag ondernemers wat hun op lange termijn gewenste vermogensstructuur is (als men die tenminste heeft!). ${ }^{7}$

Dat breng ons direct op één van de twee belangrijkste vragen in het kader van onderzoek naar de vermogensstructuur, namelijk of, en zo ja welke, vermogensverhoudingen door ondernemingen worden nagestreefd (de andere vraag is 'Waarom?'). Uit de vraaggesprekken blijkt dat de bufferfunctie c.q. het weerstandsvermogen het belangrijkste aspect van de vermogensstructuur is. Van de ondervraagden hanteert $96 \%$ een ratio op basis waarvan deze bufferfunctie wordt gestuurd. De resterende 4\% geeft aan geen optimale vermogensverhoudingen na te streven. Dit betreft winstgevende middelgrote ondernemingen met een zeer sterke vermogenspositie waardoor de vraag van de gewenste vermogensverhoudingen zich niet heeft voorgedaan. Blijkbaar is de vermogensmarkt niet in staat deze ondernemingen te disciplineren en hen aan te sporen tot optimale vermogensverhoudingen.

Alhoewel $66 \%$ van de geinterviewden de boekwaarde van weinig of geen betekenis acht voor de waardering van zijn onderneming spreken allen $(100 \%)$ over de vermogensstructuur in termen van boekwaarden. $74 \%$ noemt geen reden waarom de vermogensstructuur slechts in termen van boekwaarden van belang is (behalve 'iedereen doet het zo dus doen wij het ook zo') en vaak wordt de vraag ernaar ook als buitenissig ervaren. In relatie tot de bufferfunctie van de vermogensstructuur wordt wel enkele keren het argument genoemd dat het eigen vermogen in marktwaardetermen juist in slechte tijden verdwijnt als sneeuw voor de zon terwijl het uitgedrukt in boek- waarden ten tijde van recessie nog enigermate bestand is tegen sterke waardedalingen.

Daarnaast geven alle ondernemingen een zekere range aan waarbinnen, of waarboven, de vermogensverhoudingen zich zouden moeten bevinden. Deze bandbreedte ligt tussen de 5 en 10 procentpunten. Dit ondersteunt de intuïtie van Myers (1984) en de analyse van Fisher et al. (1989), dat aanpassings-, i.c. recapitalisatiekosten een belangrijke rol spelen en dat een range van, bijvoorbeeld, eigen/vreemd vermogen de relevante maatstaf van de vermogensstructuur is.

In tabel 3 treft $u$ een overzicht aan van de gewenste vermogensverhoudingen. Daaruit blijkt dat men in veel gevallen de klassieke ratio eigen/ vreemd vermogen niet de meest relevante maatstaf voor het weerstandsvermogen acht. Slechts $54 \%$ hanteert een optimale vermogensstructuur in termen van eigen vermogen als percentage van het lange balanstotaal. Deze groep kan nog worden onderscheiden in $42 \%$ die een optimale proportie eigen vermogen nastreeft en $12 \%$ die een ondergrens hanteert. Daarnaast streeft $42 \%$ naar een vermogensstructuur die in andere termen is gedefinieerd. De helft daarvan $(20 \%)$ hanteert een solvabiliteitsmaatstaf waarbij in plaats van het eigen vermogen het garantievermogen wordt genomen en/of het korte in plaats van het lange balanstotaal. Voor de ondernemingen die de achtergestelde leningen bij het groepsvermogen optellen en zodoende een bepaald percentage garantievermogen nastreven is het aspect van de schuldcapaciteit blijkbaar een belangrijker element van de vermogensstructuur dan de bufferfunctie van het eigen vermogen. Een andere mogelijke verklaring voor het hanteren van het garantievermogen als maatstaf van de vermogensstructuur is dat dit hen beter convenieert aangezien deze ondernemingen gemiddeld meer achtergestelde leningen hebben dan de overige. De resterende $22 \%$ hanteert een variëteit aan maatstaven die in de ogen van de betrokken ondernemingen een betere indicator vormen van het weerstandsvermogen dan een klassieke solvabiliteitsratio. Voorbeelden daarvan zijn het eigen vermogen als percentage van de omzet of uitgedrukt in termen van de maandelijkse loon- 


\section{MAB}

som. De wijze waarop men de gewenste vermogensstructuur definieert blijkt niet gecorreleerd te zijn met grootte of winstgevendheid.

De constatering dat slechts $54 \%$ de verhouding eigen/vreemd vermogen hanteert bij het bepalen van de vermogensstructuur heeft belangrijke consequenties voor empirisch onderzoek naar de vermogensstructuur. Slechts voor deze $54 \%$ is het zinvol om determinanten van de op lange termijn gewenste verhouding eigen/vreemd vermo-

Tabel 3: De gewenste vermogensstructuur

\begin{tabular}{lr}
$\begin{array}{l}\text { Gewenste vermogensstructuur in termen } \\
\text { van eigen vermogen als percentage } \\
\text { van de lange balans }\end{array}$ & $\begin{array}{r}\text { aantal } \\
\text { onder- } \\
\text { nemingen }\end{array}$ \\
\hline $25-30 \%$ & 2 \\
$30 \%$ & 4 \\
$35 \%$ & 5 \\
$40 \%$ & 11 \\
$45 \%$ & 3 \\
$50 \%$ & 1 \\
hoe meer hoe beter & 1 \\
\end{tabular}

Gewenste vermogensstructuur gedefinieerd in andere termen:

Eigen vermogen als percentage van korte balans

Garantievermogen als percentage van lange of korte balans

Overige

eigen vermogen $=15 \%$ van omzet in kas, rentedragend vreemd vermogen minimaliseren,

financiering afhankelijk van projecten, interest coverage,

eigen vermogen $=$ nettofinancieringspo-

sitie,

geen ratio's (pecking order),

eigen vermogen $=3$ maandsalarissen, evenwicht tussen eigen vermogen en liquide middelen

Géén gewenste lange termijn vermogensstructuur gen empirisch te analyseren. Voor de overige ondernemingen zou men zoeken naar de verklaring van een financieringsgedrag dat niet bestaat, zij streven immers een andere, of geen vermogensverhouding na. Het probleem voor onderzoekers, inclusief Cools en Spee (1990), is bovendien dat niet bekend is welke ondernemingen een 'afwijkende' vermogensstructuur nastreven. Ware dat wel het geval geweest dan zou immers die groep ondernemingen bij de analyse buiten beschouwing kunnen worden gelaten.

Men zou kunnen verwachten dat de gewenste vermogensverhoudingen significant verschillen per bedrijfstak, dit is echter niet het geval. Hierop is één uitzondering: de $10 \%$ groothandelsondernemingen hanteren de laagste hoeveelheid eigen vermogen. Vier van de vijf hanteren een gewenste proportie eigen vermogen die ligt tussen de $25 \%$ en $30 \%$ en de vijfde wenst zich met minimaal $1 / 3$ eigen vermogen te financieren. Als reden daarvoor noemt men het fungibele karakter c.q. liquiditeit van de activa, waarmee indirect wordt gewezen op een laag bedrijfsrisico in samenhang met een goede beschermingsmogelijkheid in het geval van tegenvallende resultaten, namelijk het (weliswaar met verlies) verkopen van de voorraden. De gewenste vermogensverhoudingen zijn niet significant gerelateerd aan de omvang van de ondernemingen.

$90 \%$ van de ondernemingen streeft naar een bepaalde hoeveelheid eigen of garantievermogen, hetgeen erop wijst dat weerstandsvermogen als het belangrijkste aspect van de vermogensstructuur wordt beschouwd. In het bijzonder betreft dit het gevaar dat de rente- en aflossingsverplichtingen aan de verschaffers van vreemd vermogen niet kunnen worden nagekomen. Afgezien van off-balance sheet financiering komt het aspect van de bescherming van de geleende hoofdsommen tot uitdrukking in de hierboven genoemde balansverhoudingen. Met betrekking tot off-balance sheet financiering geeft $68 \%$ van de ondernemingen aan dat balansverhoudingen, dus cosmetica, een rol spelen bij het kiezen voor off-balance constructies. Dit cijfer wekt verbazing inzoverre dat deze ondernemingen ervan uitgaan dat de vermogensmarkt en/of de banken daar 


\section{MAB}

niet doorheen zien en varen op de verhoogde solvabiliteit ten gevolge van de balansverkorting.

Een ander aspect van de solvabiliteit vormen de rente- en aflossingsverplichtingen aan verschaffers van vreemd vermogen. Voor geen van de ondernemingen spelen, naast de genoemde balansverhoudingen, de aflossingsverplichtingen een aparte rol van betekenis. Immers, gegeven een gewenste hoeveelheid vreemd vermogen, behoeven per saldo nooit aflossingsbetalingen te worden gedaan. De interestbetalingen daarentegen vormen voor sommige ondernemingen wél een afzonderlijk aspect van de financiële structuur, tot uitdrukking komend in de interest coverage ratio. Tabel 4 geeft aan in hoeverre de rentedekking voor ondernemingen een punt van aandacht vormt. Hieruit blijkt dat aan de interest coverage beduidend minder belang wordt gehecht dan aan de vermogensverhoudingen. Slechts $8 \%$ van de ondervraagden acht de rentedekking van groter belang dan de vermogensstructuur.

\section{Tabel 4: Het belang van de interest coverage}

a de interest coverage ratio zelf: wordt gevolgd

'is zo hoog, speelt niet'

minimumniveau wordt gehanteerd

een optimum wordt nagestreefd

niet van belang

b de interest coverage ten opzichte van de gewenste vermogensverhoudingen:

belangrijker

even belangrijk

minder belangrijk

niet van belang

\section{Grenzen aan solvabiliteit}

Wanneer ondernemingen streven naar bepaalde vermogensverhoudingen op lange termijn geven zij daarmee impliciet aan dat er gevaren, en derhalve kosten, verbonden zijn aan het 'uit evenwicht zijn'. Gezien de eerder genoemde hoofd- functie van de vermogensstructuur, te weten weerstandsvermogen, is de verwachting gerechtvaardigd dat met name gevaren kleven aan te weinig eigen- c.q. garantievermogen. Dat dit inderdaad het geval is blijkt uit tabel 5 .

\section{Tabel 5: Waarom een ondergrens aan solvabiliteit?}

bufferfunctie, geen tegenslagen op kunnen vangen $\quad 98 \%$ speelt niet

$$
\frac{2 \%}{100 \%}
$$

specifieke gevaren van te lage solvabiliteit:

in bewegingsvrijheid beperkt door banken verlies aan flexibiliteit

verlies van vertrouwen bij stakeholders onvoldoende ruimte voor afboeking good will

De genoemde bufferfunctie van het eigen of garantievermogen heeft in de eerste plaats betrekking op het recht van verschaffers van vreemd vermogen om in het uiterste geval faillissement aan te vragen. Voordat het zover is wordt de onderneming in haar vrijheid beperkt doordat haar leencapaciteit afneemt en zij vervolgens hogere rente moet betalen. Daarbij moeten we ons overigens realiseren dat het blote feit van een hogere rente wel de winst negatief beïnvloedt, maar niet de waarde van de onderneming! De hogere rente is een vergoeding van het risico dat nu gedragen wordt door de verschaffers van het vreemd vermogen maar wat anders terecht was gekomen op de schouders van de aandeelhouders. De aandeelhouders zouden weliswaar een hogere winst hebben gezien, maar tevens een bijbehorend hoger risico per gulden eigen vermogen, en per saldo zou de door hen gepercipieerde marktwaarde onveranderd zijn gebleven.

Het blijkt dat naarmate het eigen vermogen van een onderneming hoger is, haar management minder oog heeft voor de gevaren van te lage solvabiliteit. Dit is verrassend voor zover solvabiliteit betrekking heeft op de langere termijn. Weerstandsvermogen is nodig in tijden van te lage rendementen maar het kan slechts worden versterkt in tijden van relatieve voorspoed. Met andere woorden eigen vermogen moet worden opgebouwd wanneer het niet nodig is. Zeker wanneer 


\section{MAB}

verlies wordt geleden dreigt het gevaar van een neerwaartse spiraal. Het eigen vermogen wordt aangetast maar toch is er geld nodig voor uitbreidings- of vervangingsinvesteringen. Vanwege de verliessituatie is het aantrekken van risicokapitaal te duur, terwijl banken slechts bereid zijn te lenen wanneer de balansverhoudingen verbeteren, hetgeen nu juist onmogelijk is. Blijkbaar zijn niet alle ondernemingen zich van een dergelijk gevaar voldoende bewust.

Naast een ondergrens voor solvabiliteit kunnen ook aan een te hoog weerstandsvermogen nadelen kleven, deze nadelen treft $u$ aan in tabel 6 . Ook hier geldt dat er een significante relatie bestaat tussen de $18 \%$ ondernemingen die geen gevaar zien of daar nooit over heeft nagedacht en de feitelijke hoeveelheid eigen vermogen; deze ondernemingen hebben eerder te weinig dan te veel eigen vermogen en zij verwachten niet dat deze situatie zich in de toekomst zal wijzigen.

Tabel 6: Gevaren van te veel eigen vermogen

dalend rendement op eigen vermogen

$52 \%$

overliquiditeit

geen gevaar

nooit over nagedacht

speelt niet

$28 \%$

$12 \%$

$6 \%$

$2 \%$

$100 \%$

In deze tabel uit zich het kernprobleem van de vermogensstructuur. Modiglani en Miller (1958) hebben aangetoond dat de waarde van de onderneming niet wijzigt wanneer de verhouding eigen/ vreemd vermogen wijzigt.

Het verwachte rendement op eigen vermogen daalt wanneer de proportie eigen vermogen toeneemt, maar dat is conform het lagere risico dat de aandeelhouder loopt.

Met andere woorden, de aandeelhouder heeft geen reden tot klagen wanneer om deze reden zijn winst per aandeel daalt, het bijbehorende risico is immers ook lager.

Risico heeft altijd een prijs, dus waarom ook nu niet?

\section{Determinanten van de vermogensstructuur}

Nadat in de vorige paragraaf de vraag is behandeld welke vermogensstructuur wordt nagestreefd is nu de vraag aan de orde: 'Waarom?', met andere woorden de determinanten van de gewenste vermogensstructuur. Deze sluiten direct aan bij de determinanten die empirisch getoetst zijn in Cools en Spee (1990). Het belangrijkste voordeel van het stellen van vragen over de bepalende factoren van de financiële structuur is de afwezigheid van sommige meetfouten. Meetfouten kunnen ontstaan doordat de betreffende determinant slechts kan worden benaderd door middel van een proxy. Voorbeelden zijn de 'asset (3' als proxy voor bedrijfsrisico, de logaritme van de omzet voor ondernemingsomvang, of winst plus afschrijvingen voor cash flow. Daarnaast kan van meetfouten sprake zijn wanneer een determinant afgeleide is van een achterliggende, uiteindelijk bepalende factor. Bijvoorbeeld bedrijfstak als surrogaat voor activasamenstelling en deze laatste als maatstaf voor bedrijfsrisico. Slechts door middel van vraaggesprekken kan worden nagegaan of een determinant 'in zuivere vorm' van invloed is op de vermogensstructuur. In tabel 7 treft u per determinant aan in welke mate deze bepalend wordt geacht voor de vermogensstructuur. De antwoorden op deze vragen en de discussie daarover hebben een goed inzicht verschaft in de vermogensstructuurkeuze van beursondernemingen. Maar, nogmaals, deze inzichten kunnen helaas niet in extenso tot uitdrukking wor-

Tabel 7: Determinanten van de gewenste vermogensstructuur

Bedrijfsrisico:

$\begin{array}{lr}\text { ja, direct } & 80 \% \\ \text { indirect } & 18 \% \\ \text { nee } & 2 \%\end{array}$

Activasamenstelling:

ja

$78 \%$

nee $22 \%$

Winstgevendheid:

ja

$26 \%$

nee

$74 \%$ 
Grootte:

direct

via risico

nee
Bedrijfstak:
direct
via risico/activasamenstelling
typisch voor handel
bedriifstak bestaat niet
nee

Aftrekbaarheid rentekosten:

belangrijk

enige invloed

nauwelijks/verwaarloosbaar

niet

'Pecking order':

ja

intern, EV, W

alleen intern

nee

afwijkingen bij acquisities

Verwachte rentestanden spelen een rol:

alleen binnen $\mathrm{V}$

alleen bij uitzetten gelden

nee

Kapitaalmarkt-verwachtingen spelen een rol bij aantrekken extern vermogen:

bij keuze EV versus WV

speelt niet

nee

$86 \%$

$8 \%$

$6 \%$

den gebracht in deze publikatie, deels om redenen van vertrouwelijkheid, deels omdat sommige inzichten moeilijk objectiveerbaar zijn.

\section{7.a Bedrijfsrisico}

In lijn met Cools en Spee (1990) komt uit de vraaggesprekken pregnant naar voren dat de belangrijkste, zo niet enige, bepalende factor van de gewenste vermogensstructuur het bedrijfsrisico is. $98 \%$ van de ondernemingen is dit van mening, waarbij $18 \%$ aangeeft dat dit risico indirect tot uiting komt in andere factoren, zoals activasamenstelling of winstgevendheid. De enige onderneming die dit niet onderschrijft heeft een buitengewoon hoge solvabiliteit en (stabiele) winstgevendheid waardoor het probleem van de vermo- gensstructuur in het geheel niet speelt. Wanneer naast bedrijfsrisico tevens andere determinanten worden genoemd blijkt vrijwel altijd dat de betreffende determinant een maatstaf vormt voor het bedrijfsrisico. Dit geldt in het bijzonder voor activasamenstelling en bedrijfstak, maar ook voor winstgevendheid en grootte.

De verklaring voor het bedrijfsrisico als de primordiale determinant van de vermogensstructuur moet worden gezocht in de werking van verschillende agency mechanismen. Het management heeft zijn reputatie meestal voor $100 \%$ verbonden aan het succes van één onderneming, de werkgelegenheid van veel werknemers is verbonden aan die ene onderneming, hetzelfde geldt voor afnemers met garantierechten, leveranciers van specifieke produkten, enzovoort. Deze groepen stakeholders zullen bij het afsluiten van contracten hogere risicopremies eisen naarmate de kans op 'financial distress' hoger is. Dus naarmate het operationele risico hoger is zal men daar minder financieel risico (minder vreemd vermogen) aan willen toevoegen teneinde het totale risico zoveel mogelijk te beperken.

\section{7.b Activasamenstelling}

Uit tabel 7 blijkt tevens dat ook de activasamenstelling in sterke mate bepalend wordt geacht voor de financiering van ondernemingsactiviteiten. De twee belangrijkste soorten activa die daarbij worden genoemd zijn materiële vaste activa en vlottende activa, in het bijzonder voorraden. Naarmate voorraden meer fungibel zijn en het gevaar van incourantheid kleiner is wordt relatief meer vreemd vermogen aangetrokken. Dit heeft twee oorzaken. Op de eerste plaats kunnen deze activa snel en met weinig verlies worden verkocht, hetgeen een zekere bescherming biedt voor de hoofdsommen van het vreemd vermogen. Hetzelfde argument is uiteraard van toepassing op de andere hoofdcomponent van de vlottende activa, de post debiteuren. De mogelijkheid van cessie van debiteuren is belangrijker naarmate de kwaliteit van de debiteurenportefeuille hoger is. Daarnaast blijkt de proportie vlottende activa negetief gecorreleerd te zijn met de verhouding vaste/variabele kosten en daarmee met de operationele hefboom, die samen met fluctua- 


\section{MAB}

ties in de omzet de bepalende factor vormt voor het bedrijfsrisico. Zodoende vormt de hoeveelheid voorraden een proxy voor het bedrijfsrisico, waarbij, ceteris paribus, een hogere voorraad leidt tot een lager bedrijfsrisico.

Met betrekking tot de post materiële vaste activa worden twee componenten onderscheiden die ieder een tegengesteld effect hebben op de verhouding vreemd/eigen vermogen. De belangrijkste component wordt gevormd door vaste activa die in het kader van het produktieproces een specifieke functie hebben, met name machines, grote installaties, specifieke vervoersmiddelen, enzovoort. Deze activa wenst men te financieren met eigen vermogen. De redenen hiervoor zijn dezelfde als voor voorraden, maar dan tegengesteld. Deze activa hebben weinig alternatieve aanwendingsmogelijkheden en een lage liquidatiewaarde, zeker wanneer de resultaten in de hele bedrijfstak onder druk staan. Bovendien geldt, hoe groter de post materiële vaste activa des te sterker de operationele hefboom en des te hoger het operationele risico. En, zoals we eerder zagen, men wil een hoog operationeel risico, als het ware compenseren met een laag financieel risico omdat een informele financiële reorganisatie c.q. een faillissement blijkbaar zeer hoge (agency) kosten met zich meebrengt. De andere component van de materiële vaste activa betreft het meer courante onroerend goed, in het bijzonder kantoorpanden. Deze beïnvloeden niet zozeer de vaste kosten en daarmee het operationele risico, omdat ze vrij gemakkelijk kunnen worden gehuurd of via sale en lease back van de balans kunnen verdwijnen, maar zij zijn van belang voor het aantrekken van vreemd vermogen. Courant onroerend goed kan direct worden gebruikt voor het aantrekken van hypothecaire leningen, dan wel indirect via een negative pledge of positieve hypotheekverklaring, met andere woorden, de verpandbaarheid van deze activa is maatgevend. (Enkele ondernemingen lieten weten uitsluitend omwille van de banken onroerend goed op de balans te hebben staan, liever hadden zij deze panden geleased of gehuurd zodat zij zich volledig op hun kernactiviteiten kunnen concentreren.) Dit geeft aan dat de post materiële vaste activa een te grove eenheid is om te dienen als proxy voor theoretische determinanten. In het bijzonder het gebruik van deze post als proxy voor verpandbaarheid van activa, zoals bijvoorbeeld in Titman en Wessels (1988) en Cools en Spee (1990) is hiermee hoogst twijfelachtig geworden.

\section{7.c Winstgevendheid}

Slechts een kwart van de ondervraagden geeft aan dat een structurele stijging van de winstgevendheid leidt tot minder gewenst eigen of achtergesteld vermogen. In de cross-sectie analyse in het vorige artikel bleek de winstgevendheid echter een van de drie belangrijkste determinanten van de vermogensstructuur te zijn, waarbij bovendien de tegengestelde relatie werd gevonden (hoe hoger de feitelijke winstgevendheid, des te hoger de proportie eigen vermogen). Dit verschil zou onder meer verklaard kunnen worden doordat gevraagd is naar de invloed van een structurele stijging van de winstpotentie, terwijl de winstgevendheid in de vorige analyse was gebaseerd op het resultaat van slechts twee jaren. Belangrijker is echter dat gevraagd is naar de gewenste financiële verhoudingen, terwijl in het vorige artikel de feitelijke vermogensstructuur werd geanalyseerd.

Hieruit blijkt duidelijk de paradoxale relatie tussen winstgevendheid en solvabiliteit. Als de winstgevendheid stijgt neemt het eigen vermogen toe terwijl juist in een situatie van toenemende winstgevendheid er geen behoefte is aan een versterkte solvabiliteit, sterker nog, een kwart van de ondernemingen zou genoegen nemen met een lagere solvabiliteit wanneer de stijgende rentabiliteit een structureel karakter heeft. Uit het positieve verband tussen winstgevendheid en feitelijke solvabiliteit moet daarom worden geconcludeerd dat een aantal winstgevende ondernemingen graag meer over investeringsmogelijkheden zou beschikken zodat de toegenomen leencapaciteit ten gevolge van de groei van het eigen vermogen ten volle zou kunnen worden benut. Deze constatering wordt bevestigd door het feit dat voor $18 \%$ van de ondernemingen de solvabiliteit hoger is dan gewenst, terwijl slechts $4 \%$ haar eigen-vermogenspositie wenst te verbeteren. Bovendien kan worden gewezen op het opmerkelijke gege- 


\section{MAB}

ven dat de liquiditeitenmassa van het Nederlandse bedrijfsleven, voor zover aangehouden bij banken in Nederland, is gestegen van 47 miljard gulden in 1983 tot 110 miljard in 1990.

\section{7.d Ondernemingsomvang}

De derde factor die volgens Cools en Spee (1990) een belangrijke rol speelt ter verklaring van het financieringsgedrag is de grootte van de onderneming, hoe groter des te lager de solvabiliteit. Uit de vraaggesprekken blijkt dat slechts $4 \%$ van de ondernemingen een lagere solvabiliteit wenst wanneer zij in omvang zouden verdubbelen. Enkelen veronderstelden bij een verdubbeling wel een afname van het risico doordat de activiteiten meer gespreid zouden zijn; aldus zou met een lagere solvabiliteit kunnen worden volstaan. Echter een directe relatie tussen financiële structuur en omvang van de onderneming werd doorgaans van de hand gewezen. Dit betekent dat ondernemingsgrootte een indicator moet zijn voor meer fundamentele ondernemingskenmerken die wél bepalend zijn voor de vermogensstructuur. Daarmee blijft de positieve correlatiecoëfficiënt tussen omvang en risico die we vonden in het vorige artikel een raadselachtige waarneming die vraagt om een nadere analyse, bijvoorbeeld door het totale bedrijfsrisico te meten en niet slechts, door middel van de 'asset $\beta$ ', het systematisch deel ervan.

\section{7.e Bedrijfstak}

In de tabel lezen we dat $88 \%$ de bedrijfstak van invloed acht op de vermogensstructuur. Dit hoge percentage wordt vrijwel volledig verklaard doordat de twee samenstellende elementen van bedrijfsrisico, te weten omzetschommelingen en activasamenstelling (indicatief voor de kostenstructuur) bepaald worden door de bedrijfstak waarin men opereert. Daarmee vormt de bedrijfstak weliswaar een bepalende, maar slechts indirecte 'determinant' voor ondernemingsfinanciering.

\section{7.f Belastingvoordeel van vreemd vermogen} Hetgeen opvalt bij de aftrekbaarheid van interest is niet het aantal ondernemingen dat daar enige of een belangrijke invloed aan toekent. Het is eerder opmerkelijk dat voor $34 \%$ de fiscale aftrekbaar- heid niet of nauwelijks van invloed is op de door hen gewenste vermogensverhoudingen. Het belastingvoordeel van vreemd vermogen levert een rechtstreekse cash-bate op en is de enige factor die in de gestyleerde wereld van Modigliani en Miller $100 \%$ vreemd vermogen tot de optimale vermogensstructuur maakt.

Dit wijst nogmaals op het belang dat ondernemingen hechten aan de vermogensstructuur als instrument voor het beheersen van de insolventierisico. Een dalend rendement op eigen vermogen en een toename van de liquiditeit worden als belangrijkere nadelen genoemd van een hoge eigen vermogenspositie dan het gederfde belastingvoordeel van rentedragend vreemd vermogen, twee Nobelprijzen voor Modigliani (1984) en Miller (1990) ten spijt.

\section{7.g Pecking Order}

Myers (1984) zet static trade-off theorieën, die zeggen dat ondernemingen streven naar vaste vermogensverhoudingen, tegenover zijn dynamische pecking order verhaal waarin de vermogensstructuur per saldo een gevolg is van de winstgevendheid in combinatie met het dividendbeleid. Eerder zagen we dat $96 \%$ van de ondernemingen in zijn financieringsbeleid streeft naar een of meer vaste ratio's, variërend van de verhouding eigen/vreemd vermogen tot eigen vermogen in relatie tot de maandelijkse loonsom of de liquide middelen. Tegelijkertijd zien we dat $92 \%$ een financieringsvolgorde hanteert simultaan met het streven naar vaste vermogensverhoudingen. De 'strijd' tussen beide theorieën lijkt daarmee beslist. Voorop staat dat men bepaalde vermogensverhoudingen wenst aan te houden. Deze gewenste vermogensstructuur wordt vervolgens door middel van de pecking order gerealiseerd: op de eerste plaats intern financieren, vervolgens vreemd vermogen aantrekken, totdat de solvabiliteitsgrens is bereikt en het eigen vermogen met behulp van derden moet worden versterkt. De $56 \%$ die in ieder geval van acquisities afwijkt van de pikorde betreft ondernemingen die het gebruik van aandelen als betaalmiddel bij overnames verkiest boven betaling in contanten. Daaruit zou men kunnen concluderen dat deze ondernemingen van mening zijn dat hun aandeel 


\section{MAB}

is overgewaardeerd, tenzij andere betalingsmogelijkheden zijn uitgesloten.

\section{7.h Rente- en koersverwachtingen en emissiekosten}

De belangrijkste conclusie die uit de vraag naar de rol van renteverwachtingen kan worden getrokken is dat $92 \%$ van de ondernemingen van mening is dat zij de rente kunnen voorspellen. Aangezien de kapitaalmarkt vrijwel perfect is en de mogelijkheden voor arbitragewinsten verwaarloosbaar zijn is dit een opmerkelijk gegeven. Dat $86 \%$ bij de keuze tussen eigen en vreemd vermogen rekening houdt met de koersontwikkeling van het eigen aandeel wekt minder verbazing, aangezien men over meer informatie beschikt dan de markt. De kosten van een aandelenemissie (2 a $3 \%$ ) daarentegen speelt voor geen van de ondernemingen een rol bij de keuze tussen eigen en vreemd vermogen. Dit betekent dat niet zozeer de emissiekosten een onderdeel vormen van de recapitalisatiekosten als wel het plotselinge verwateringseffect wat optreedt bij een aandelenemissie. In het bijzonder speelt daarbij een rol dat het soms moeilijk is een overtuigend signaal naar de markt te geven, hetgeen betekent dat de signalling kosten hoog zijn.

\section{7.i Personal touch}

Ten slotte, het zoeken naar determinanten van de vermogensstructuur zoals dat hierboven en in het vorige artikel is geschied, veronderstelt dat ondernemingskenmerken bepalend zijn voor het financieringsgedrag. Wanneer echter deze beslissingen sterk afhankelijk zouden zijn van de persoonlijke voorkeuren van de belangrijkste betrokkenen in de onderneming, zou het verklaren van de vermogensstructuur wellicht beter aan andere gedragswetenschappers kunnen worden overgelaten, bijvoorbeeld psychologen. De mate waarin subjectieve voorkeuren een rol spelen bij ondernemingsfinanciering is weergegeven in tabel 8 . Niet zozeer de grote betekenis van psychologie en emotionaliteit ( $88 \%$ ), dan wel het persoonsgebonden karakter van ondernemingsfinanciering ('ik heb nou eenmaal een hekel aan convertibles', 'Financiering wordt zeker niet door de business bepaald, maar door de personen' of
'Ik doe graag zaken met mensen met wie ik het een beetje kan vinden') is voor een bedrijfseconoom de bevestiging van bange vermoedens. De rol van persoonlijke voorkeuren zal echter minder groot zijn dan de cijfers in de tabel doen vermoeden omdat de aard en cultuur van een onderneming zorg draagt voor een zekere voorselectie van haar financiële topmanagement. Het spreekt voor zich dat de twee vragen dermate algemeen gesteld zijn dat daaraan verder weinig conclusies te verbinden zijn. Uit de cijfers kunnen we slechts lezen dat, nog los van het feit dat elke onderneming tot op zekere hoogte uniek is, de bedrijfse-

Tabel 8: Ondernemingsfinanciering, economie of psychologie?

Psychologie, emotionaliteit, spelen een rol bij ondernemingsfinanciering:

ja nee

Ondernemingsfinanciering is persoonsgebonden:

ja, sterk van invloed

$30 \%$

van invloed

$32 \%$

van enige invloed

$28 \%$

nee/nauwelijks

$10 \%$

conomie er op eigen kracht nooit in zal slagen het laatste stukje van de vermogensstructuur-puzzel te vinden.

\section{Samenvatting en conclusies}

De vraaggesprekken met bestuursleden van vijftig beursondernemingen hebben ons geleerd dat Willard Carlton gelijk had toen hij in 1978 neerschreef dat belangrijke aspecten van de financieringsbeslissingen van ondernemingen niet ten volle door de vermogensmarkt zichtbaar worden gemaakt. Of dit een verwijt inhoudt, c.q. moet inhouden, aan het adres van het gangbare neoklassieke financieringsonderzoek dat zich beperkt tot abstracte analyses van de prijsvorming op vermogensmarkten, is echter de vraag. Alhoewel de hier gepresenteerde resultaten voor deze stelling een groot aantal aanknopingspunten bieden, is het lastig daarvoor een sluitend bewijs te leveren. Dat zou ons immers al snel voe- 


\section{MAB}

ren naar een discussie over de efficiënte markthypothese, een discussie die ik graag elders zou willen voeren.

De belangrijkste conclusies van deze interviewstudie, mede in relatie tot de twee voorgaande artikelen over theorie respectievelijk empirie van de vermogensstructuur kunnen als volgt worden samengevat.

Nederlandse beursondernemingen streven niet naar maximalisatie van de aandeelhouderswaarde van de onderneming maar naar winstgevende groei, gericht op continuiteit. Dit brengt belangrijke agency problemen met zich mee, in het bijzonder voor de verhouding tussen aandeelhouders en management.

Slechts $54 \%$ streeft een proportie eigen vermogen in termen van het lange balanstotaal na. Daarom lijkt het weinig zinvol de verhouding eigen/vreemd vermogen van ondernemingen te willen verklaren. Daarentegen, $84 \%$ streeft naar een vaste verhouding eigen of garantievermogen ten opzichte van het korte of lange balanstotaal. Rekening houdend met specifieke kenmerken van de overige ondernemingen speelt solvabiliteit c.q. weerstandsvermogen voor $96 \%$ van de ondernemingen een rol van meer of mindere betekenis. Vervolgens tracht men via de pecking order deze gewenste vermogensstructuur te handhaven, namelijk interne financiering, vreemd respectievelijk extern eigen vermogen.

De belangrijkste en meest eenduidige conclusie luidt dat het bedrijfsrisico de bepalende determinant is voor de gewenste vermogensstructuur. Naarmate het bedrijfsrisico hoger is streeft men naar een lager financieel risico teneinde het totale risico te beperken. De verklaring daarvoor moet worden gezocht in het bestaan van belangrijke agency problemen, zoals de reputatie van het management die volledig is verbonden aan het lot van de eigen onderneming. Daarnaast zijn er agency relaties met werknemers in specifieke functies, leveranciers van specifieke produkten, garantierechten van afnemers, enzovoort die een informele financiële reorganisatie c.q. faillissement tot een kostbare zaak maken.

De activasamenstelling is de meest bepalende factor voor het bedrijfsrisico en daarmee indirect voor de vermogensstructuur. De materiële vaste activa zijn enerzijds van belang vanwege courant onroerend goed dat als onderpand kan dienen bij het aantrekken van vreemd vermogen en anderzijds specifieke installaties en machines die men wil financieren met eigen vermogen en eventueel een gedeelte lang vreemd vermogen. Vlottende activa, in bijzonder fungibele voorraden en een goede debiteurenportefeuille behoeven met weinig eigen vermogen gefinancierd te worden. De bedrijfstak acht men wel van belang voor de financiële structuur, maar deze blijkt bij nader inzien een proxy te zijn van activasamenstelling en omzetrisico, de twee elementen van bedrijfsrisico. Opvallend is dat 34\% nauwelijks enig belang hecht aan het belastingvoordeel van overmatig eigen vermogen. Het dalend rendement op eigen vermogen en de liquiditeitstoename vindt men een belangrijker nadeel van vreemd vermogen financiering dan de gederfde cash belastingvoordelen. De stijging van het eigen vermogen bij een toenemende winstgevendheid, gecombineerd met een lagere solvabiliteitswens bij structurele winststijging wijzen erop dat winstgevende ondernemingen onvoldoende investeringsmogelijkheden voor handen hebben aangezien zij de toegenomen leencapaciteit niet ten volle benutten.

Ten slotte kwam aan de orde dat ondernemingsfinanciering in belangrijke mate persoonsgebonden is, hetgeen betekent dat de bedrijfseconoom zijn aspiratieniveau bij het verklaren van de vermogensstructuur moet limiteren.

\section{Literatuur}

Brigham, E. F., 1966, 'An analysis of Convertible Debentures' Journal of Finance, Vol. 21, (March), pp. 35-54.

Carleton, W. T., 1978, 'An Agenda for More Effective Research in Corporate Finance', Financial Management, (Winter), pp. 7-9.

Cools, C., 1990, 'Determinanten van de vermogensstructuur' Maandblad voor accountancy en bedrifseconomie, jrg. 64, nr. 9 (september), pp. 368-377.

Cools, C. en Spee, R. J., 1990, 'De vermogensstructuur van Nederlandse beursondernemingen, 1977-1988' Maandblad voor Accountancy en Bedrijfseconomie, jrg. 64, nr. 10 (oktober), pp. 409-428.

Fisher, E. O., Heinkel, R. and Zechner, J., 1989, 'Dynamic Capital Structure Choice: Theory and Tests' Journal of Finance, vol. 44, no. 1 (March) pp. 19.

Jensen, M. C. en Meckling, W., 1976, 'Theory of the Firm: 


\section{MAB}

Managerial Behavior, Agency Costs and Ownership Structure' Journal of Financial Economics, vol. 4 (October), pp. 305-360.

Modigliani, F. en Miller, M. H., 1958, 'The Cost of Capital, Corporation Finance and the Theory of Investment' The American Economic Review Vol. 48 (June), pp. 261-297.

Modigliani, F. en Miller, M. H., 1963, 'Corporate Income Taxes and the Cost of Capital: A Correction' American Economic Review Vol. 53 (June), pp. 433-443.

Moerland, P. W., 1989, De overnemingsmarkt: theorie, empirie en regelgeving, Vuga Uitgeverij B. V. 's-Gravenhage

Myers, S. C., 1984, 'The Capital Structure Puzzle' Journal of Finance Vol. 39 (July), pp. 575-592.

Pinegar, J. M. en Wilbricht, L., 1989, 'What Managers Think of Capital Structure Theory: A Survey' Financial Management, Vol. 18 , No. 4 (Winter), pp. 82-91.

Titman, S. en Wessels, R. E., 1988, 'Determinants of Capital Structure Choice' Journal of Finance, Vol. 43, No. 1 (March), pp. 1-19.

Toy, N. et. al., 1974, 'A Comparitive International Study of Growth, Profitability and Risk as Determinants of Corporate Debt Ratios in the Manifacturing Sector' Journal of Financial and Quantitative Analysis (November), pp. 337-347.

\section{Noten}

1 Mijn bijzondere dank gaat uit naar de vierenzestig ondernemingsbestuurders met wie ik de vraaggesprekken heb mogen voeren en van wie de namen zijn opgenomen in bijlage 1. Niet alleen vormen zij de raison d'être van dit onderzoek maar bovendien was hun zeer bereidwillige medewerking een conditio sine qua non.

Ik ben Dr. A. W. A. Boot, Drs. P. J. W. Duffhues, Prof. Dr. P. W. Moerland, Drs. J. C. H. A. M. Ramaekers RA, Dr. M. B. M. van der Ven en de redactie van het MAB erkentelijk voor commentaar op een eerdere versie van dit artikel.

2 Andere onderwerpen die tijdens de vraaggesprekken zijn besproken, zoals shareholder value, ondernemingswaarde, de kosten van vermogen, dividendbeleid, aandelenemissies, opstelling van de jaarrekening en de rol van de accountant, zullen in andere publikaties aan de orde worden gesteld. 3 In de internationale financieringsliteratuur is over de vermogensstructuur twee maal eerder onderzoek gedaan op basis van enquêtes, te weten Toy, et al. (1974) en Pinnegar en Willbricht (1989). Daarnaast heeft Brigham (1966) gebruik gemaakt van vragenlijsten bij een onderzoek naar de motieven voor de emissie van converteerbare obligaties.

4 In het geval van twee ondernemingen (KLM en Heineken) was de geïnterviewde weliswaar de eerst verantwoordelijke voor financiële zaken (de 'CFO'), maar geen lid van de raad van bestuur. In één geval (Internatio-Müller) was het financiële lid uit de raad van bestuur in de betreffende periode niet beschikbaar en is gesproken met de corporate treasurer.

5 Het is van belang hier een onderscheid te maken tussen quasi en echte agency problemen. Er is reeds sprake van een quasi agency relatie tussen aandeelhouders en 'de onderneming' wanneer ondernemingen publiekelijk aangeven dat zij niet het belang van hun aandeelhouders nastreven. Er ontstaat echter pas een 'echt' agency probleem wanneer aandeelhouders niet zouden weten dat het management niet primair het belang van de aandeelhouders nastreeft, of wanneer zij zegt te streven naar winstmaximalisatie maar in feite slechts haar eigen belangen zou behartigen. Naast deze agency relaties tussen management en aandeelhouders hebben we nog te maken met agency problemen tussen aandeelhouders/management en vreemd vermogen verschaffers (bijvoorbeeld het 'bondholder wealth expropriation' verhaal, zie Cools (1990).

6 Bijvoorbeeld Océ-van der Grinten heeft haar lease debiteuren op de geconsolideerde balans staan, hetgeen de solvabiliteit negatief beïnvloedt aangezien de lease debiteuren voornamelijk met vreemd vermogen zullen zijn gefinancierd. Bijvoorbeeld DAF daarentegen heeft haar lease activiteiten ondergebracht in een $100 \%$ dochter (DAF Finance), waardoor het eigen vermogen van DAF Trucks relatief hoger lijkt. Een voorbeeld van gescheiden onroerend goed maatschappijen treffen we aan bij Ahold. Omdat onroerend goed met relatief veel vreemd vermogen is gefinancierd heeft dit hetzelfde positieve effect op de balans als het afspinnen van lease activiteiten.

7 Van discrepanties tussen feitelijke en gewenste financiële verhoudingen is bijvoorbeeld sprake wanneer de huidige solvabiliteit onvoldoende is als gevolg van achterblijvende rendementen of een slecht emissieklimaat. Omgekeerd zou een te hoog eigen vermogen veroorzaakt kunnen worden door het ontberen van rendabele investeringsmogelijkheden. In zulke gevallen zijn de kosten voor aanpassing van de vermogensstructuur blijkbaar hoger dan het voordeel dat de gewenste solvabiliteit zou opleveren. Myers (1984) heeft gewezen op het belang van dergelijke aanpassingskosten, en Fischer, Heinkel en Zechner (1989) hebben vervolgens beargumenteerd dat niet een bepaalde verhouding eigen/vreemd vermogen de meest relevante maatstaf van de vermogensstructuur is, maar een eigen/vreemd vermogen-range.

\section{Bijlage 1}

Namen van personen en ondernemingen met wie de gesprekken ziin gevoerd

Jhr. Drs. P. C. W. Alberda van Ekenstein

Drs. C. B. Alberti

Dr. M. Albrecht en Drs. P. F. Brouwers

Drs. J. B. H. M. Beks RA en Drs. J. L. van

Oordt

Dr. S. Bergsma

Ph. A. Betsch

G. C. Biesbroek RA

Drs. R. W. J. M. Bonnier RA

H. A. D. van den Boogaard en

E. F. B. Heuver RA

Drs. C. J. Brakel

Drs. B. C. Brix

P. M. van den Broecke en

G. C. van der Wouden

Drs. J. Brouwer

KLM

Elsevier

Hoogovens

Heineken

Akzo

Hagemeijer

VRG-Groep

KNP

VMF Stork

Wolters Kluwer

Hunter Douglas

NBM-Amstelland

Bührmann-

Tetterode

W. T. J. Dijkman RA 
G. C. Dohmen

Ir. D. van Dordt

Mr. R. A. Fokma en Drs. R. N. M. Siepman Drs. F. J. Frank

Ir. J. G. Haars

Drs. R. F. Hendriksen RA en

Mr. R. R. Hendriks

F. Hetzenauer

Drs. C. H. van der Hoeven

Drs. J. G. ten Hoonte

J. Janssen

A. de Jong

P. Korpershoek

Drs. R. B. Lenterman RA

R. M. Lubbers

Drs. H. J. A. F. Meertens

Prof. Drs. H. Meij RA en

Drs. W. C. J. Angenent RA

Drs. H. H. Meijer RA en

Drs. J. A. van der Heijden

C. G. Mes

Volmac
van der Giesen-
de Noord
Internatio-Müller
CSM
Boskalis
VOC
Tulip Computers
Ahold
KBB
Content Beheer
OPG
Econosto
Nedlloyd
Hollandia Kloos
Océ-van der
Grinten
Unilever
DAF
Frans Maas

E. J. Nederkoorn RA en

Mr. J. H. A. Olde Loohuis Fokker

Drs. J. F. A. van den Nieuwenhuyzen Begemann

C. Oosthuizen

R. C. H. Pleijers

Mr. F. P. Polman RA

Drs. A. L. Rasterhoff

Drs. F. H. M. de Rujiter

Drs. A. N. G. Ruis RA

Drs. D. J. Schoenmaker

Mr. D. Sinninghe Damste

en Drs. P. L. Beijnes

Mr. A. P. Timmermans

C. J. Valkenaars RA

Drs. G. Verhagen RA en

Dr. S. D. Eikelboom

Dr. H. C. Verlage

J. Versloot RA

P. H. van der Vorm en A. Joosse

Ir. R. van Yperen

Drs. J. Zantman, Drs. J. H. Goris en

Drs. P. E. J. Boost
Wessanen

Sphinx

Borsumy Wehry

Shell Int. Petr.

Mij.

Van Besouw

Schuitema

Twijnstra Gudde

HBG

DSM

Gamma

Pakhoed

Grasso

Center Parcs

H. E. S. Beheer

Beers

Philips 